\title{
Chickpea Genetic Resources Regeneration and Safety Duplication in Georgia
}

\author{
Avtandil Korakhashvilii ${ }^{1, *}$, David Kirvalidze ${ }^{2}$ \\ ${ }^{1}$ National Academy of Sciences of Georgia, Georgia \\ ${ }^{2}$ Cultivating New Frontiers in Agriculture, Georgia
}

Copyright $\mathrm{O} 2016$ by authors, all rights reserved. Authors agree that this article remains permanently open access under the terms of the Creative Commons Attribution License 4.0 International License

\begin{abstract}
A set of most released 46 chickpea accessions maintained in the collection of the Legume's Genebank of the Agrarian University of Georgia (AUG) was regenerated using advance growing technology of seed pilling and nano herbicides. For AUG grain legumes are mandatory crops in the frame of country regulations. The level of genetic diversity and the affectivity of new germplasm acquisition for the collection enrichment were evaluated. All of them, safety duplicated 6 years ago, needed regular regeneration for future breeding works, as well as for sending to genebanks of our collaborators and breeder in abroad in accordance with international agreements. A new material was obtained from all the accessions special pilot plots of chickpea. Recently acquired new germplasm contributed all of new entire collection, i.e. almost $100 \%$ of collected diversity originated from the recently obtained accessions. Remarkable is also, that all accession carries a unique germination, not present in the remaining collection. Field and lab analysis revealed the importance of collecting missions for the enrichment of collections of genetic resources. They will be used locally and sent to international scientific institutions.
\end{abstract}

Keywords Chickpea Genotypes, Safety Duplication, Pilling Technology, Nano Herbicides, Germplasm, Genebank, Regeneration, Landraces

\section{Introduction}

In Georgia the chickpea (Cicer arietinum L.) is a traditional grain legume crop during above 31 centuries (except recent 2 centuries) and influenced the food supply chain, especially in warmer and drier Eastern Georgia regions. This crop is not a dominant legume species in Georgian agriculture now, where other grain legumes such as haricot bean and soybean predominate. Nevertheless, demand for chickpea is growing here at the present time also due to the interesting nutritive value of grain and recently changing climate creating favorable conditions for chickpea cultivation. Moreover, chickpea grain are considered as an important source of minerals and vitamins necessary for human and animal nutrition and provide a protein-rich supplement to the diet of vegetarians, as well as for children food $[3,7,13]$.

\section{Materials and Methods}

The chickpea genetic resources collection maintained in the genebank of the AUG, as this institution is responsible for legume crops for Georgia. Presently, comprises predominantly foreign accessions $(12 \%)$, in addition to a limited number of Georgian landraces and registered cultivars (only 88\%). From the aspect of effective management of the plant genetic resources it is beneficial if the acquisition of any new accessions into the established collection is associated also with proteome and genome based analysis using molecular markers besides morphological and agronomical analyses $[9,10,18]$.

This type of characterization has lately been common in plant "genebanking" at AUG. The requirements for chickpea accession characterization at the molecular marker level also result from the threat of duplications maintenance, genetic erosion due to the loss of rich domestic accessions and the sensitivity of plants to environmental and biological stresses (biotic and abiotic) as well. It is extremely important to study the genetic composition of existing genetic resources (lines, cultivars, landraces, wild relatives, progenitors), obtained from farmer's field and during expeditions inside of country (1996-2012), because they provide a chance to find new and useful genes or alleles for future breeding works[15].

PCR-based techniques and revealing of microsatellite sequences in plant genomes helped to overcome problems with low polymorphism detected also in cultivated chickpea. The conservativeness of microsatellite flanking regions in the genus Cicer L. gives the possibility to use already available microsatellite chickpea markers at the polymorphism detection in other chickpea accessions $[15,19]$ 
The preferred markers for these purposes are single-locus co-dominant microsatellite markers whose usefulness in chickpea has already been reported [2]. These markers helped to overcome limited polymorphism within cultivated varieties of chickpea. The STMS chickpea marker map is accessible with several hundreds of STMS markers and the chickpea marker map including different molecular markers has been developed $[16,17]$.

The objectives of this study were to analyze the level of diversity at microsatellite loci within the monitored set of our chickpea genetic resources, and to use this tool for the monitoring of diversity enrichment in a chickpea collection by new germplasm acquisitions [1].

Among of regeneration, the accompanying aim of scientific-research work was determination of biological behavior and resistance of chickpea germplasm collection against disease and pests on the base of regeneration action, as well as determination of their germination potential in three various soil and climate conditions.

From the AUG grain legumes Genebank of Forty-six chickpea accessions were used for the study including one Georgian registered cultivar and six landraces collected across Georgia (Table 1). Thirty-five of them (32 originated from Georgia and 3 from selection) were added to the collection as accessions enriching the already existing national collection. Their way to the national collection was through germplasm exchange with ICARDA and ICRISAT. During operations and adoption some of the accessions were relabeled. In additional, six genotypes originated from $\mathrm{M}$ Asia countries, members of our group in cooperation with ICARDA's Tashkent office [12, 14].

Georgia's genetic-resource program of grain legumes is committed to collect, evaluate, document and renew the biodiversity and use it for genetic enhancement of legumes. This diversity occurs in 2 forms - wild relatives of legumes species and farmer selected crop landraces. The last ones are the result of thousands of years of risk-averse selection by the farmers themselves, but the wild relatives are equally important, for they are constantly adapting in order to survive changes in climate, soil, pollution levels, exposition and other aspects of their environment.

It's not only chickpea and other legumes species which are diverse. Much of the land area of Georgia was once range and shrub land. Even just now, there is a vast array of species and ecotypes of annual legumes living out there, capable of surviving some of the most arid (East Georgia) and humid (West Georgia) conditions.

Table 1. Chickpea accessions collection of Georgia;

\begin{tabular}{|c|c|c|c|c|c|}
\hline No. by DR & Accession code/name & Origin & No. by DR & Accession code/name & Origin \\
\hline 1 & Sur 1 & Georgia & 24 & SP 15 & Georgia \\
\hline 2 & Sur 2 & Georgia & 25 & SP 16 & Georgia \\
\hline 3 & Sur 3 & Georgia & 26 & SP 17 & Georgia \\
\hline 4 & Sur 4 & Georgia & 27 & SP 18 & Georgia \\
\hline 5 & Gur 1 & Georgia & 28 & SP 19 & Georgia \\
\hline 6 & Gur 2 & Georgia & 29 & SP 20 & Georgia \\
\hline 7 & Gur 3 & Georgia & 30 & SP 21 & Georgia \\
\hline 8 & Shir 1 & Georgia & 31 & SP 22 & Georgia \\
\hline 9 & Shir 2 & Georgia & 32 & SP 23 & Georgia \\
\hline 10 & Shir 3 & Georgia & 33 & IC 13 & India \\
\hline 11 & Shir 4 & Georgia & 34 & IC 42 & India \\
\hline 12 & Shir 5 & Georgia & 35 & IC 54 & India \\
\hline 13 & Shir 6 & Georgia & 36 & Bak 03 & Azerbaijan \\
\hline 14 & Shir 7 & Georgia & 37 & Bak 08 & Azerbaijan \\
\hline 15 & SP 1 & Georgia & 38 & Bak 12 & Azerbaijan \\
\hline 16 & SP 4 & Georgia & 39 & $\mathrm{Baz}$ & Turkmenistan \\
\hline 17 & SP 5 & Georgia & 40 & Tash & Uzbekistan \\
\hline 18 & SP 6 & Georgia & 41 & Tash & Uzbekistan \\
\hline 19 & SP 7 & Georgia & 42 & ICARDA & Syria \\
\hline 20 & SP 8 & Georgia & 43 & ICARDA & Syria \\
\hline 21 & SP 12 & Georgia & 44 & Arag & Georgia \\
\hline 22 & SP 13 & Georgia & 45 & Eliks & Georgia \\
\hline 23 & SP 14 & Georgia & 46 & Zeda & Georgia \\
\hline
\end{tabular}


At the modern stage of the mankind development the special importance is given to the maintenance of the plant genetic resources diversity in the ex-situ conditions as scientific technical progress in the form of breeding species and hybrids sharply increased the danger of the decrease of this diversity. This issue is especially actually, first of all for those countries which belong to the primary and secondary hearths of cultural plant origin. Georgia which enters the Front Asia hearth of most important cultural plant origin is regarded as the primary hearth of origin of barley, millet, flax, vetch, pea, chickpea, alfalfa, clover and it is important that Georgia is the origin center of wild chickpeas origins, which is proved by historical sources and with results of wide scale collecting missions held in 20-30-ies of the last century. In in-situ conditions field cultures local forms diversity was maintained in 60 -ies of the last century which is witnessed by collecting missions held in this period $[4,6]$.

By the resolutions of Academy of Agricultural Sciences and the Ministry of Agriculture of Georgia, the GAU has been carrying out mandate of scale rehabilitation works with legumes, include studies of local legumes germplasm collection, conservation and enhancement.

\section{Results and Discussion}

The GAU has been engaged in food legumes collection and breeding over 80 years, with programs of their improvement. National agricultural research systems of Georgia made affords to increase production of food legumes both vertically (through high inputs, including irrigation) and horizontally (increasing land area). Recently, however, national program scientists and the research administrators in Georgia have realized that diversification is needed in a legume-based, sustainable cropping system.

During last 16 years, a group of scientists and post-graduate students of GAU have been carrying out wide scale rehabilitation work of legumes. These works are implemented mainly through the financial support of International institutions such as ICRISAT, GTZ, USDA, ACDI-VOCA, ICARDA, USAID, WB, etc. As a result of such activity, we have collected 692 samples of food and feed legumes as follows: Soybeans - 68; Faba Been 24; Chickpea- 46; Lentil- 36; Pisum- 7, Haricot beans 83; as well as annual and perennial grasses: Trifolium- 89 , Astragalus22; Medicago- 88; Onobrychis- 46; Melilotus-19; Lupinus16; Galega- 19; Vicia- 112; Lathyrus- 17; For recording this material we are using special computer program, kindly supplied by ICARDA. To Chickpea crop pays one of biggest attention [8,11].

The chickpea genetic resources collection maintained in the Genebank of the Agrarian University of Georgia as well as this institution is responsible mandatory for legumes in our country. A set of 46 chickpea accessions maintained in the collection (ex-situ) of the Genebank. In 2011-2015 those accessions were regenerated (as winter and spring crops) on special plots using advance growing technology of seed pilling and using of nano herbicides (nanocooper C-076) in accordance with Special Plan of regeneration, enhancement and protection.

The level of genetic diversity and the effectively of new germplasm acquisition for the collection enrichment were evaluated. All of them collected last time permanently needed regeneration for future breeding work, as well as for sending to genebanks of our collaborators and breeders in abroad. At the same time, by our group of scientists selected and officially released 3 new varieties of chickpea: Zedazeni, Aragvi and Eliksiri.

In 2014 regenerated material was obtained from all the accessions special pilot plots of chickpea. Recently acquired new germplasm contributed all of new entire collection, i.e. almost $100 \%$ of collected diversity originated from the recently acquired accessions. Remarkable is also, that all accession carries a unique germination, not present in the remaining collection. Field and lab analysis revealed the importance of collecting missions for the enrichment of collections.

The overall of objective the food legume germplasm regeneration for future improvement program of Georgia (chickpea, lentil, beans, and soybean) is to increase the productivity and sustainability of the farming system in partnership with AUG and Georgian farmers. This objective is pursued through improving the methodologies for food legume breeding, training of AUG staff in renewal of germplasm, improvement of production practices and genetic stocks with resistance to various biotic and abiotic stresses, sharing of the improved germplasm with AUG and its evaluation under targeted environments for identification of improved lines for future use.

During the same year regeneration process under report, all of 46 wild sort-populations and selected varieties of chickpea were made to combine resistance to various biotic and abiotic stresses in varying agronomic backgrounds in various soil conditions. The improved genetic materials were shared in the form of 3 different sets of trials for 3 different nurseries. During regeneration and safety duplication of germplasm, interesting by our point of view results obtained in agronomic characteristics in three various regions of Georgia. From 46 accessions $71 \%$ had good germination in pilot plots of East Georgia, same 46 accessions had only $32 \%$ and 52\% germination potential in pilot plots of West Georgia and pre mountain regions of North Georgia correspondently.

A successful germplasm enhancement effort requires the development of an international research infrastructure with participation of European countries, including Georgia. The opportunity for interaction afforded by IPGRI groups will be invaluable in developing a long-term plan for effectively applying classical and contemporary techniques to the germplasm needs of chickpea producers. From 2016 Georgia will develop an official Catalog of released crops, include above mentioned legumes.

The availability of appropriate information about chickpea germplasm of Georgia is a critical success factor in breeding and biodiversity protection factor in the agri-food sector's, 
global responsibility for the production of such food and the preservation of the quality of natural environments.

We understand that free exchange of chickpea germplasm on a worldwide basis between plant scientists, especially of our region is vital as genetic diversity is the foundation of all plant improvement programs. Recently, Georgian breeders are using above mentioned 3 new varieties of chickpea named as Zedazeni, Aragvi and Eliksiri in their breeding work successfully and have a good opportunity for next period of time development. Those chickpea new varieties are very popular by point of view of commercialization Georgian farmers are planting those varieties on a big trail. Above mentioned varieties are very popular in Azerbaijan too.

The integration of European countries in IPGRI Working Groups, give good opportunity for European country's scientists and professionals, who are engaged in the collection, systematization, development and use of modern chickpea diversity, which could support wild relative and landrace successful breeding work and agro-biodiversity protection for the development of sustainable agriculture.

Decentralization of breeding activities of scientists of Georgia with ICARDA in South Caucasus and Central Asia resulted in identification of promising lines in chickpea. In accordance with IPGRI descriptors and methodology, safety duplication and cleaned and packaged new germplasm (harvest of 2014) departed to genebanks of AUG (Tbilisi, Georgia), ICARDA (Aleppo, Syria) and Svalbard Global Seed Vault (Spitsbergen, Norway) for the benefit of present and future generations.

\section{REFERENCES}

[1] Ahmad F., Slinkard A. E. (1992): Genetic relationships in the genus Cicer L. as revealed by polyacrylamide gel electrophoresis of seed storage proteins. Theoretical and Applied Genetics, 84: 688-692.

[2] Buhariwalla H .K., Jayashree B., Eshwar K., Crouch J.H. (2005): Development of ESTs from chickpea roots and their use in diversity analysis of the Cicer genus. BMC Plant Biology, 5: 16.

[3] AGLADZE G., KORAKHASHVILI A., 1999. Grass landraces of Georgian arid pastures. Report of a Working Group on Forages. Elvas, Portugal, 97 p.

[4] Buddenhagen I., 1983. Breeding strategies for stress and disease resistance in developing countries. Ann.Rev. \# 21, $409 \mathrm{p}$.

[5] Cingilli H., Altinkut A., Akcin A. (2005): The use of microsatellite markers in the annual and perennial Cicer species growing in Turkey. Biology, 60: 93-98.

[6] Cooke R.J., Reeves J.C. (2003): Plant genetic resources and molecular markers: variety registration in a new era. Plant Genetic Resources: Characterization and Utilization, 2-3:
81-87.

[7] KORAKHASHVILI A., (2001), Grain Legumes Collection and Improvement in Georgia, IPGRI Report Working Group on Grain Legumes, Krakow, Poland. pp. 67-68, www.ipgri.cgiar.wgfg

[8] KORAKHASHVILI A., (2001), New Growing Technologies of Grain Legumes and Their role in Farmers Economics. Caravan, Aleppo, Syria, pp 23-29.

[9] KORAKHASHVILI A., at al (2001), Vetches and Chicklings in Central Asia and the Caucasus. m. "Caravan", \#13, Aleppo, Syria. pp.14-15. www.icarda.cgiar.pdf

[10] KORAKHASHVILI A.,at al.(2011) Research of Cinnamonic Calcareous Soil Fertilizing Systems for Pastures of Akhaltsikhe District, Communications in Soil Sciences and Plant Analysis, Taylor and Francis, USA, vol. 42, \#7, pp. 753-767.

[11] KORAKHASHVILI A., (2014), Regeneration and Conservation of Chickpea Genetic Resources of Georgia, International Conference on Enhanced Genepool Utilization, Cambridge, United Kingdom, pp. 34-37.

[12] Nguyen T.T., Taylor P.W.J., Redden R.J., Ford R. (2004): Genetic diversity estimates in Cicer using AFLP analysis. Plant Breeding, 123: 173-179.

[13] Radhika P., Gowda S.J.M., Kadoo N.Y., Mhase L.B., Jamadagni B.M., Sainani M.N., Chandra S., Gupta V.S. (2007): Development of an integrated intraspe-cific map of chickpea (Cicer arietinum L.) using two recombinant inbred line populations. Theoretical and Applied Genetics, pp. 209-216.

[14] Sethy N. K., Shokeen B., Edwards K.J., Bhatia S. (2006): Development of microsatellite markers and analysis of intraspecific genetic variability in chickpea (Cicer arietinum L.). Theoretical and Applied Genetics, 112: 1416-1428.

[15] Shan F., Clarke H.J., Yan G., Plummer A., Siddique K.H.M. (2007): Identification of duplicates and fingerprinting of primary and secondary wild annual Cicer gene pools using AFLP markers. Genetic Resources and Crop Evolution, 54: 519-527.

[16] Singh A., Devarumath R. M., Ramarao S., Singh V.P., Raina S.N. (2008): Assessment of genetic diversity, and phylogenetic relationships based on ribosomal DNA repeat unit length variation and Internal Transcribed Spacer (ITS) sequences in chickpea (Cicer arietinum) cultivars and its wild species. Genetic Resources and Crop Evolution, 55: 65-79.

[17] Tekeoglu M., Rajesh P.N., Muehlbauer F. J. (2002): Integration of sequence tagged microsatellite sites to the chickpea genetic map. Theoretical and Applied Genetics, 105: 847-854.

[18] Udupa S.S., Robertson L. D., Weigand F., Baum M., Kahl G. (1999): Allelic variation at (TAA $)_{n}$ micros-atellite loci in a world collection of chickpea (Cicer arietinum L.) germplasm. Molecular and General Genetics, 261: 354-363.

[19] Virk P.S., Newbury H.J., Jackson M.T., Ford-Lloyd B. V. (1995): The identification of duplicate accessions within a rice germplasm collection using RAPD analysis. Theoretical and Applied Genetics, 90: 1049-1055. 